\title{
MENINGKATKAN KUALITAS MASYARAKAT DENGAN ENTREPRENEURSHIP
}

\author{
Siti Hanifa Sandri*, Wahyi Busyro, Siti Samsiah, Bakaruddin \\ Prodi Keuangan dan Perbankan, Fakultas Ekonomi dan Bisnis \\ *Email: sandri_adh@yahoo.com
}

\begin{abstract}
Abstrak
Tingkat Pengangguran di Indonesia menunjukkan angka relatif berfluktuatif dibandingkan di negara - negara maju. Salah satu usaha untuk mengurangi jumlah pengangguran adalah dengan menciptakan lapangan pekerjaan salah satunya dengan entrepreneurship. Pertumbuhan ekonomi yang meningkat sangat mungkin akan meningkatkan peluang kesempatan berusaha. Salah satu yang harus diasah kemandiriannya adalah adik-adik panti asuhan melalui kegiatan pelatihan berbasis wirausaha. Melalui pelatihan ini diharapkan dapat memberikan pengetahuan dan menumbuhkan jiwa kewirausahaan bagi adik-adk Panti Asuhan. Kegiatan meningkatkan kualitas masyarakat dengan entrepreneurship melalui pelatihan kreatifitas balon hias dan bucket bunga wisuda yang dilaksanakan pada tanggal 8 April 2017 di Panti Asuhan Anak As - Sallam Pekanbaru. Kegiatan ini berjalan lancar yang dihadiri oleh 30 peserta. Peserta terlihat sangat antusias dengan materi yang diberikan. Hasil dari kegiatan ini dicapai dalam kegiatan yang berlangsung satu hari. Semua hasil yang dibuat peserta dikumpulkan dan di lakukan evaluasi, diberi masukan dan selanjutnya dapat diperbaiki lagi. Berdasarkan dari hasil kegiatan dapat diidentifikasi tingkat pemahaman peserta pengabdian sebesar $80 \%$ memahami konsep yang diberikan penyaji dan pentingnya memiliki kualitas dalam diri yaitu bentuk kreatifitas guna bersaing pada era golabal saat ini.
\end{abstract}

Kata kunci: Kualitas, Masyarakat, Enterprenuer

\section{PENDAHULUAN}

Ekonomi Indonesia dihadapkan pada krisis ekonomi global yang kini sedang terjadi, dimana Indonesia merupakan negara yang sedang berkembang dan fundamental ekonomi yang belum kuat akan merasakan secara langsung pengaruh dari luar. Globalisasi membuat kompetisi semakin ketat dan transfer pengetahuan semakin cepat. Dunia sudah memasuki peradaban keempat dengan sebutan era kreatif yang menempatkan kreativitas dan inovasi sebagai motor penggerak pertumbuhan ekonomi. Industri kecil menengahmerupakan bagian dari dunia usaha nasional yang mempunyai kedudukan, potensi dan peranan yang sangat strategis dalam mewujudkan pembangunan nasional. Di Indonesia sendiri perhatian terhadap industri kecil menengah telah menjadi hal yang penting bukan hanya untuk memperkuat struktur perekonomian nasional tetapi juga untuk penyerapan tenaga kerja dan sebagai wahana yang sangat strategi untuk distribusi barang dan jasa.

Industri kecil menengah memegang peran yang besar apabila dikaitkan dengan masalah - masalah ekonomi dan sosial dalam negeri seperti tingginya tingkat kemiskinan, besarnya jumlah pengangguran, ketimpangan distribusi pendapatan, proses pembangunan yang tidak 
merata serta masalah urbanisasi dengan segala efek - efek negatifnya. Maka diharapkan keberadaan atau perkembangan usaha kecil menengah diharapkan dapat memberikan kontribusi yang signifikan terhadap upaya - upaya penanggulangan masalah tersebut di era perdagangan bebas dan semakin gencarnya proses globalisasi.

Sebagai negara yang sedang berkembang, Indonesia termasuk masih kekurangan wirausahawan. Hal ini dapat dipahami karena kondisi pendidikan di Indonesia masih belum menunjang kebutuhan pembangunan sektor ekonomi. Karena hampir seluruh sekolah masih didominasi oleh pelaksanaan pendidikan dan pembelajaran yang konvensional.

Kemajuan suatu negara didukung oleh para wirausahawan. Wirausaha dikenal juga dengan istilah entrepreneur yang pertama kali diperkenalkan oleh Richard Cantillon di Perancis pada tahun 1755 dalam bukunya yang berjudul Essai sur la nature du commerceen. Wirausaha (entreprenuer) diartikan sebagai seorang inovator dan penggerak pembangunan. Wirausaha adalah individu yang memiliki pengendalian tertentu terhadap alat alat produksi dan menghasilkan lebih banyak daripada yang dapat dikonsumsunya atau dijual atau ditukarkan agar memperoleh pendapatan (McClelland, 1961).

Penelitian Eko Agus Alfianto mengatakan wirausaha adalah jalan pekerjaan seseorang yang dijalankan dengan kemungkinan memperoleh keuntungan dan kerugian yang tak terhingga berdasarkan skala kualitas seseorang tersebut hingga untuk melangkah berwirausaha diperlukan pribadi-pribadi tangguh, pribadi pantang menyerah, percaya diri, kemampuan mental emosional dan kemampuan membaca peluang.

Kualitas penduduk adalah tingkat/taraf kehidupan penduduk yang berkaitan dengan kemampuan dalam pemenuhan kebutuhan seperti pangan, sandang, perumahan, kesehatan dan pendidikan. Dari berbagai faktor yang mempengaruhi kualitas penduduk salah satunya yakni segi pendidikan dimana tingkat pendidikan merupakan modal dasar dalam mengembangkan kemampuan intelektual seseorang. Melalui pendidikan seseorang akan mampu meningkatkan kemampuan kognitif, afektif dan psikomotoriknya. Hal ini diwujudkan dalam bentuk kemampuan menyelesaikan berbagai permasalahan dengan mengembangkan kreativitasnya.

Tingkat pendidikan penduduk Indonesia relatif lebih rendah dibandingkan penduduk di negara negara maju. Maka dari itu untuk mendorong pertumbuhan ekonomi, wirausaha dapat mempengaruhi seluruh perekonomian, khususnya pada pasar tenaga kerja. Pertumbuhan yang meningkat sangat mungkin akan meningkatkan peluang kesempatan berusaha.

\section{Rumusan Masalah}

Meningkatkan kualitas hidup masyarakat dengan berwirausaha.

\section{Tujuan}

Tujuan dari pengabdian masyarakat ini adalah : memberikan pengetahuan dan kemampuan bagi adik-adik panti asuhan tentang peluang berwirausahaan.

\section{Manfaat}


Dengan dilaksanakannya pengabdian masyarakat ini maka diharapkan adik-adik panti asuhan memiliki kemampuan dan keterampilan peluang kewirausahaan yang nantinya dapat bermanfaat untuk menghadapi era global.

\section{METODE PENGABDIAN}

Pengabdian ini dilaksanakan di Panti Asuhan Anak As - Sallam Pekanbaru. Pelaksanaan ini melibatkan beberapa pihak, diantaranya pengusaha balon hias dan buket bunga wisuda yang merupakan alumni dari UMRI. Melalui pelatihan ini diharapkan dapat memberikan pengetahuan dan jiwa kewirausahaan bagi adik-adik dipanti Asuhan As- Sallam ini di akan datang.

Keterampilan tidak selalu didapatkkan dibangku sekolah maka dari itu pentingnya memiliki kreatifitas sehingga dapat meningkatkan kualitas dalam berwirausaha. Pelaksanaan pengabdian ini dilakukan dengan metode ceramah dan langsung mencontohkan praktek kerjanya dan selanjutnya peserta diberikan waktu untuk dapat menyelesaikan sesuai kreatifitas dan kemampuan masing masing.

Pelaksanaan pengabdian ini dilakukan dengan tiga tahap. Pertama yakni tahap persiapan. Pada tahap ini anak - anak di bagi menjadi beberapa kelompok dan alat yang digunakan dalam pengabdian ini adalah balon dengan berbagai bentuk, pompa balon tangan, printan contoh balon yang akan di bentuk. Untuk buket bunga wisuda dipersiapkan gunting, kain planel, lem tembak, plastic dan sedotan sebagai tangkai buket bunga.
Tahap selanjutnya merupakan tahap kegiatan pengabdian dengan memberikan contoh lalu, peserta mengembangkan kemampuan mereka. Tahap terakhir adalah tahap evaluasi atas hasil yang dihasilkan masing - masing peserta. Masukan dan perbaikan juga dilaksanakan pada tahap ini. Evaluasi dilakukan dengan melihat hasil akhir yakni kerapian dan keunikan yang dihasilkan. Data diambil dari pemahaman peserta dalam menyimpulkan apa yang disampaikan oleh penyaji dan dilanjutkan dengan tanya jawab.

Pencapaian tujuan pengabdian ini $80 \%$ peserta telah memahami dan mengetahui kemampuan mereka akan pengembangan kreatifitas sehinga dapat membaca peluang pentingnya kualitas dalam diri. Pentingnya kualitas ini dalam bentuk karya sehingga dapat membuka peluang untuk berwirausaha sedini mungkin. Hasil dari pengembangan kemampuan peserta rapi dan unik akan dipasarkan oleh penyaji yang sekaligus wirausaha yang telah sukses.

\section{HASIL DAN PEMBAHASAN}

Kegiatan meningkatkan kualitas masyarakat dengan entrepreneurship melalui pelatihan kreatifitas balon hias dan buket bunga yang dilaksanakan pada tanggal 8 April 2017 di Panti Asuhan Anak As Sallam Pekanbaru. Kegiatan ini berjalan lancar yang dihadiri oleh 30 peserta. Peserta terlihat sangat antusias dengan materi yang diberikan. Hal ini terlihat dari semua peserta mengikuti dengan baik dari awal hingga akhir kegiatan.

Materi tentang kewirausahaan, yang berarti perlunya meningkatkan kualitas masyarakat dalam 
berwirausaha dalam bentuk kreatifitas balon danbuketbungaserta mencari target pasar baru dan beda dari yang lain (unik).

Hasil dari kegiatan ini dicapai dalam kegiatan yang berlangsung satu hari. Semua hasil yang dibuat peserta dikumpulkan dan di lakukan evaluasi, diberi masukan dan selanjutnya dapat diperbaiki lagi. Selama proses berlangsung tanya jawab dan diskusi antara peserta dan penyaji tetap dilakukan guna meningkatkan pemahaman sehingga memperoleh hasil yang diinginkan.

Berdasarkan dari hasil kegiatan dapat diidentifikasi tingkat pemahaman peserta pengabdian sebesar $80 \%$ memahami konsep yang diberikan penyaji dan pentingnya memiliki kualitas dalam diri yaitu bentuk kreatifitas guna bersaing pada era golabal saat ini.

Kegiatan pengabdian meningkatkan kualitas masyarakat dengan Entreprenership dapat berjalan lancar. Kegiatan ini memang dibutuhkan untuk generasi muda sedini mungkin. Diharapkan agar generasi muda ini menyadari pentingnya memiliki kualitas diri sebagai bentuk pertahanan akan keadaan ekonomi Indonesia yang sedang memasuki era global dan persaingan tenaga kerja Indonesia terhadap tenaga kerja asing. Diharapkan nantinya generasi muda saat ini dapat membuka lapangan kerja baru. Untuk itu diperlukannya pelatihan kegiatan meningkatkan kualitas masyarakat dengan Entreprenership.

Generasi muda hendaknya mengembangkan kualitas dalam diri mereka dengan berkreatifitas. Agar pendidikan yang mereka miliki tidak hanya sebatas pelaksanaan pembelajaran di sekolah saja namun berdampak juga pada kehidupan diluar sekolah. Jiwa kewirausahaan dan keterampilan hendaknya diasah juga agar menjadi generasi muda yang aktif dan membuka peluang baru di bidang ekonomi.

\section{SIMPULAN}

Pelaksanaan pengabdian ini dilakukan dengan metode ceramah dan langsung mencontohkan praktek kerjanya dan selanjutnya peserta diberikan waktu untuk dapat menyelesaikan sesuai kreatifitas dan kemampuan masing - masing.

Pemahaman peserta pengabdian sebesar $80 \%$ memahami konsep yang diberikan penyaji dan pentingnya memiliki kualitas dalam diri yaitu bentuk kreatifitas guna bersaing pada era golabal saat ini.

\section{UCAPAN TERIMAKASIH}

Terimakasih sebanyak-banyaknya untuk semua pihak yang telah mensukseskan acara pengabdian ini, baik itu pihak Panti Asuhan Assalam, Narasumber dan DosenDosen yang terlibat.

\section{DAFTAR PUSTAKA}

[1] http://www.pikiranrakyat.com/ ekonomi/2015/09/06/341264/f undamentalekonomiindonesia-tahan-menghadapitekanan

[2] http://burhan.staff.ipb.ac.id /2012/01/24/mendorongpertumbuhan-ekonomi melalui-peningkatan-jumlahwirausaha-sebuah-kerangkapenelitian/ (10 April 2017)

[3] https://www.indonesia investments.com/id/keuangan/a ngka-ekonomi- 
makro/pengangguran/item255?

(10 April 2017)

[4] http://www.pikiran-

rakyat.com/

ekonomi/2015/09/06/341264/f

undamental-ekonomi-

indonesia-tahan-menghadapi-

tekanan(10 April 2017)

[5] http://faniramdani24.

blogspot.co.id/ 2014/04/artikel-

kewirausahaan-dan-memulai

bisnis kecil.html (18 April

2017)

[6] Wiedy Murtini (2004).

Pengembangan Desain

Pembelajaran Pendidikan

Kewirausahaan di Perguruan

Tinggi dengan Pemodelan

Wirausahawan Usaha Kecil

dan Menengah Sukses.

www.uns.ac.id (18 April 2017)

[7] V. Winarto (2008).

Membangun Kewirausahaan

Sosial: Meruntuhkan dan

Menciptakan Sistem Secara

Kreatif. Makalah Seminar 22

Februari

2008.www.api.pasca.ugm.ac.id (18 April 2017) 